\title{
Relative Contribution of Demographic Characteristics on Utilization of John Harris Library, University of Benin, Nigeria
}

\author{
Luke Osamudiamen Obasuyi ${ }^{*}$ \\ John Harris Library, University of Benin, P.M.B. 1154, Benin City, Nigeria
}

*Corresponding Author

Luke O. Obasuyi, John Harris Library

\section{Article History}

Received: 24.06.2020

Accepted: 02.07.2020

Published: 16.07.2020

\begin{abstract}
This study investigated the relative contributions of demographic characteristics influencing utilization of John Harris Library, University of Benin (UNIBEN) by undergraduate students. A four point likert scale instrument with 35 questions was used to collect data. Seven questions were on demographics, ten questions on utilization of the library while 18 questions were on factors influencing utilization of the library. Respondents consist of 243 undergraduates at different levels of their studies. Data collected were analyzed using frequency distribution, percentage, mean, Pearson Product Moment Correlation, regression analysis (ANOVA). Results revealed that there is high and significant level of utilization of the library among the undergraduate students of the university. Demographic characteristics (academic discipline, level of study, gender and age) made collective significant contribution to the use of the library. Level of study made significant relative contribution towards utilization of the library. Efforts should be put in place by the managers of the library to sustain this result and improve on it.
\end{abstract}

Keywords: Library utilization, Demographics, Academic discipline, Level of study, Gender, Age.

\section{INTRODUCTION}

Utilization of academic library is a major concern of every higher educational institution because huge amount of funds are invested into the development, management and running of the libraries. In the light of the above, efforts are made by every academic institution to attract students to use the resources and services provided by the library. Several researches have been conducted to ascertain the different factors that can influence utilization of the library. Various factors such as human, demographic, economic, institutional, environmental etc. have been investigated to determine their influence on undergraduates' use of academic libraries in many countries of the world. These studies have identified varied factor under different circumstances.

Demographic characteristics have been critical factors in understanding utilization of information technology, knowledge, library resources and services especially in higher education across the globe. Demographic characteristics often provide important clues as to what factors contribute to undergraduates' use of online library resources [1]. The role played by demographic characteristics of library users is very important to the utilization of the library. Usoro, Umoren \& Akwang [2] opined that student demographics are capable of influencing their use of the library. Demographic characteristics include age, marital status, gender, academic discipline, level of study, designation, race, social background, ethnicity, religion etc. [3]. Ebijuwa and Mabawonku [4] assert that age, gender and academic discipline could be possible factors that exert influence on undergraduates' use of e-library resources in Nigeria. Oyedum [5] identified course of study as one of the variables that affect students' use of university libraries. In John Harris Library, UNIBEN, the role of undergraduate demographics on the use of the library has not been adequate studied. In this study, the relative contribution of academic discipline, level of study, gender and age on utilization of the library was investigated.

Copyright @ 2020: This is an open-access article distributed under the terms of the Creative Commons Attribution license which permits unrestricted use, distribution, and reproduction in any medium for non commercial use (NonCommercial, or CC-BY-NC) provided the original author and source are credited. 


\section{RESEARCH Questions}

Three research questions were proposed for the study.

1. What is the level of utilization of John Harris Library, University of Benin?

2. What is the joint contribution of academic discipline, level of study, gender and age on utilization of the library by undergraduates, University of Benin?

3. What is the relative contribution of academic discipline, level of study, gender and age on utilization of the library by undergraduates, University of Benin?

\section{LiTERATURE REVIEW}

Studies on the influence of demographics on utilization of university libraries by undergraduate students yielded different results in different universities across the globe. Exploring four demographic characteristics (age, gender, ethnicity and country of origin) on usage of University of Huddersfield library by undergraduates, Stone and Collins [6] revealed that there is a significant influence of demographics on library usage. At the University of Minnesota Libraries, Shane, Fransen, Peterson and Mastel [7] found both graduate and undergraduate students' use library resources and services differently based on faculty and discipline. Lopatovska and Regalado [8] assessed students' behavior across four university libraries in New York City area and found that demographics, academic requirements, work habits and disciplinary affiliations accounted for the variations in their behavior towards library use. Investigating demographic trends influencing students' engagement in online library instruction, Thill, Rosenzweig and Wallis [9] established that age, academic performance, gender, race and ethnicity were significant factors. At the Pontificia Universidad Catolica de Chile, Jara, Clasing, Gonzalez, Montenegro, Kelly, Alaron, Sandoval and Saurina [10] indicated that library use by undergraduates varied across the various disciplines and level of study in the university. On the use of library resources and services by researchers at Karanatak University, Gurikar and Gurikar [11] revealed that daily visit and use of the library is independent of gender.

In Nigeria, Onovughe and Ogbah [12] established that female students utilize the library than the male students in Delta State, South-south, Nigeria. Among medical students at the Ambrose Alli University, Ekpoma, Momodu [13] concluded that gender differences exist in library utilization among the students in that institution. Aladeniyi and Owokole [14] found that female undergraduate library users are more than their male counterparts at the University of Medical Science, Ondo. Obasuyi and Idiodi [15] reported that at the University of Benin, data collected during the 2013/2014 academic session found that the value of the library influenced its use and there was no significant difference in library use per faculty status or gender.

In South-western Nigeria, Nwezeh [16] survey at Obafemi Awolowo University Library, Ile-Ife revealed that time spent in the library increased with year of study as older students spent more hours in the library. Oyeniyi [17] study of the use of electronic resources among Library and Information Science professionals in academic libraries revealed that though male professionals scored a higher mean than the females, there was no significant difference in the utilization of e-resources in the libraries. Similarly, investigation of gender differences in the use of Federal University of Technology Library, Akure, Fumilayo [18] revealed that gender differences exist in age, marital status, Internet access, and use of advisory services in the library. Young women visit the library than young men, male graduates patronized the library than female graduates but there was no significant difference between men and women library usage.

On the use of library resources and facilities in Nigerian universities, Ebijuwa and Mabawonku [4] concluded that age, gender and academic discipline influenced utilization of electronic library resources by undergraduate students in six Federal Universities in South-west, Nigeria. Similarly, Ebijuwa [4] found that perceived ease of use and gender significantly associate with students' utilization of electronic resources in selected private universities in Nigeria. Tolulope [19] found a joint influence of demographic variables on utilization of library software by undergraduate students in Redeemers and Bowen universities. The findings also show significant relationship between gender and the use of library software. Similarly, Quadri [1] surveyed the influence of demographic factors on utilization of online library resources in two private universities and findings indicate a significant relationship between level of study and age on usage of online library resources while gender and religion did not.

In Northern Nigeria, Ahmed [20] finding indicated that there was a significant difference in the utilization of eresources based on gender at Ramat Library, University of Maiduguri. However, there was no significant difference in challenges male and female students faced utilizing e-resource in the library. Bassi and Cambel [21] study of gender difference in using three university libraries in Adamawa State showed statistical influence of gender towards the use of the libraries e-resources. 
According to Usoro, Umoren and Akwang [2], investigation at University of Uyo Library showed that age and gender influenced utilization of the library information resources. On the use of Online Public Access Catalogue (OPAC), Emiri [22] revealed that gender, age, and level of study influenced the use of OPAC at the University of Benin and Ambrose Alli University, Ekpoma. At Michael Okpara University of Agriculture Digital Library, Uzuegbu, Chukwu and Ibegwam [23] reported that gender, level of study and purpose of library visit did not influence utilization of the databases.

A comparative study of three universities by Agboola and Bamigboye [24] showed that level of study did not influence the use of the library in two of the universities while in the third there was a relationship between library use and undergraduate students academic level. Library use increased from 100 level to 500 level in the two universities while 300 level students used the library more in the third university. According to Oyedum [5] a study of the relative effects of six demographic factors influencing undergraduates' use of six university libraries in Nigeria revealed course of study was the second factor that exerts significant influence on utilization of the libraries. Ebijuwa and Mabawonku [4] study found that age made relative significant contribution towards the use of e-library resources by undergraduates but gender and academic discipline did not. From the literature reviewed above, different demographics influenced utilization of different university libraries worldwide. Therefore, it becomes pertinent to study every university library to ascertain what demographics come to play in the use of the libraries.

\section{Methodology}

The study adopted the survey research design of the correlational type. The questionnaire was used to collect data from students. A four point likert scale instrument with 35 questions was adopted. Seven questions were on demographics, ten questions on utilization of the library while 18 questions were on factors influencing utilization of library. Undergraduate students (243) in 13 various faculties were involved in the study. Convenience sampling method was adopted in this study due to lack of time, funding and ease of access to students. The questionnaire was administered on the undergraduate students at the main library of the university during the 2018/2019 academic session for a period of one week. Data collected were analyzed using frequency distribution, percentage, mean, Pearson Product Moment Correlation and ANOVA.

\section{RESULTS AND DisCUSSION \\ Demographic characteristics of the respondents}

Results in Table 1 showed that $25(10.3 \%)$ of the respondents were students from the Faculty of Education, 24(9.9\%) were from Arts, 20(8.2\%) were from Engineering, 35(14.4\%) were from Physical sciences, 10(4.1\%) were from Social science, 29(11.9\%) were from Management sciences, 50(20.6\%) were from Life sciences, $12(4.9 \%)$ were from Agriculture, 30(12.3\%) were from Pharmacy, 1(0.4\%) were from Medicine, 5(2.1\%) were from Basic medical science, $1(0.4 \%)$ was from Environmental sciences and $1(0.4 \%)$ was from the Faculty of Law. Sixty four $(26.3 \%)$ were 100 level students, 50(20.6\%) were 200 level students, 53(21.8\%) were 300 level students, 50(20.6\%) were 400 level students, 20(8.2\%) were 500 level students and 6(2.5\%) were 600 level students. Male were 139(57.2\%) and 104(42.8\%) were females, and 226(93.0\%) were aged 18-35 years, 14(5.8\%) were aged 26-30 years and 3(1.2\%) were aged 36 years and above.

The above result shows that undergraduate students from various faculties of Life Sciences, Physical sciences, Pharmacy, Management Sciences and Education used the library more than other faculties. Result also shows that students in 100 level $(26.3 \%)$ used the library more while male students $(57.2 \%)$ outnumbered the female students. Students between the ages 18 - 25 years constituted $90 \%$ users of the library. Therefore, the University Library is highly used by undergraduate students of the University. Similar result obtained by Ebijuwa and Mabawonku [25] showed that Science and Engineering students topped their respondents while male were $67.7 \%$ respondents, and students between ages $17-25$ accounted for over $85 \%$. 
Table-1: Demographic characteristics of the respondents

\begin{tabular}{|l|l|l|l|}
\hline Demographic variable & Frequency & Percentage \\
\hline Academic disciplinel/ Faculty & Education & 25 & 10.3 \\
& Arts & 24 & 9.9 \\
& Engineering & 20 & 8.2 \\
& Physical science & 35 & 14.4 \\
& Social science & 10 & 4.1 \\
& Management science & 29 & 11.9 \\
& Life science & 50 & 20.6 \\
& Agriculture & 12 & 4.9 \\
& Pharmacy & 30 & 12.3 \\
& Medicine & 1 & 0.4 \\
& Basic Medical science & 5 & 2.1 \\
& Environmental science & 1 & 0.4 \\
& Law & 1 & 0.4 \\
\hline Level of study & 100 level & 64 & 26.3 \\
& 200 level & 50 & 20.6 \\
& 300 level & 53 & 21.8 \\
& 400 level & 50 & 20.6 \\
& 500 level & 20 & 8.2 \\
& 600 level & 6 & 2.5 \\
\hline Gender & Male & 139 & 57.2 \\
& Female & 104 & 42.8 \\
\hline Age & $18-25$ years & 226 & 93.0 \\
& $26-30$ years & 14 & 5.8 \\
& $31-35$ years & 3 & 1.2 \\
\hline
\end{tabular}

Research Question 1: What is the level and percentage of utilization of the library?

Table 2 presents the information on the utilization of the library. "I spend at least one hour anytime I use the library" $(\bar{x}=3.58)$ ranked highest by the mean score rating and was followed in succession by "The library is very useful for my academic pursuits" $(\bar{x}=3.56)$, "Library resources and services are very useful to me" $(\bar{x}=3.08)$, "I use the library regularly for my study" ( $\bar{x}=3.07)$, "My intensity of using the library is high" $(\bar{x}=3.01)$, "I use the library on a daily basis to read my books only" $(\bar{x}=2.66)$, "Library materials help me in my assignment and course work" $(\bar{x}=2.50)$, "I read mainly books in the library for my academic work' $(\bar{x}=2.49)$, "I borrow books in the library for my course work" $(\bar{x}=1.70)$ and lastly "I use mainly electronic resources and databases in the library" $(\bar{x}=1.54)$ respectively.

Table-2: Utilization of the library by students of University of Benin, Edo state

\begin{tabular}{|c|c|c|c|c|c|c|c|}
\hline $\mathbf{S} / \mathbf{N}$ & Utilization of the library & 1 & 2 & 3 & 4 & $\overline{\mathbf{X}}$ & SD \\
\hline 1 & I spend at least one hour anytime I use the library & $\begin{array}{l}15 \\
6.2 \%\end{array}$ & $\begin{array}{l}10 \\
4.1 \%\end{array}$ & $\begin{array}{l}36 \\
14.8 \%\end{array}$ & $\begin{array}{l}182 \\
74.9 \%\end{array}$ & 3.58 & 0.84 \\
\hline 2 & The library is very useful for my academic pursuits & $\begin{array}{l}7 \\
2.9 \%\end{array}$ & $\begin{array}{l}15 \\
6.2 \%\end{array}$ & $\begin{array}{l}57 \\
23.5 \%\end{array}$ & $\begin{array}{l}164 \\
67.5 \%\end{array}$ & 3.56 & 0.74 \\
\hline 3 & Library resources and services are very useful to me & $\begin{array}{l}25 \\
10.3 \% \\
\end{array}$ & $\begin{array}{l}30 \\
12.3 \% \\
\end{array}$ & $\begin{array}{l}89 \\
36.6 \% \\
\end{array}$ & $\begin{array}{l}99 \\
40.7 \% \\
\end{array}$ & 3.08 & 0.97 \\
\hline 4 & I use the library regularly for my study & $\begin{array}{l}16 \\
6.6 \% \\
\end{array}$ & $\begin{array}{l}38 \\
15.6 \%\end{array}$ & $\begin{array}{l}101 \\
41.6 \% \\
\end{array}$ & $\begin{array}{l}88 \\
36.2 \% \\
\end{array}$ & 3.07 & 0.88 \\
\hline 5 & My intensity of using the library is high & $\begin{array}{l}19 \\
7.8 \%\end{array}$ & $\begin{array}{l}46 \\
18.9 \%\end{array}$ & $\begin{array}{l}91 \\
37.4 \%\end{array}$ & $\begin{array}{l}87 \\
35.8 \%\end{array}$ & 3.01 & 0.93 \\
\hline 6 & I use the library on a daily basis to read my books only & $\begin{array}{l}4 \\
18.1 \%\end{array}$ & $\begin{array}{l}53 \\
21.8 \%\end{array}$ & $\begin{array}{l}88 \\
36.2 \%\end{array}$ & $\begin{array}{l}58 \\
23.9 \%\end{array}$ & 2.66 & 1.03 \\
\hline 7 & Library materials help me in my assignment and course work & $\begin{array}{l}62 \\
25.5 \% \\
\end{array}$ & $\begin{array}{l}49 \\
20.2 \% \\
\end{array}$ & $\begin{array}{l}81 \\
33.3 \% \\
\end{array}$ & $\begin{array}{l}51 \\
21.0 \% \\
\end{array}$ & 2.50 & 1.09 \\
\hline 8 & I read mainly books in the library for my academic work & $\begin{array}{l}74 \\
30.5 \%\end{array}$ & $\begin{array}{l}40 \\
16.5 \%\end{array}$ & $\begin{array}{l}64 \\
26.3 \%\end{array}$ & $\begin{array}{l}65 \\
26.7 \%\end{array}$ & 2.49 & 1.18 \\
\hline 9 & I borrow books in the library for my course work & $\begin{array}{l}141 \\
58.0 \%\end{array}$ & $\begin{array}{l}54 \\
22.2 \%\end{array}$ & $\begin{array}{l}28 \\
11.5 \%\end{array}$ & $\begin{array}{l}20 \\
8.2 \%\end{array}$ & 1.70 & 0.97 \\
\hline 10 & I use mainly electronic resources and databases in the library & $\begin{array}{l}151 \\
62.1 \%\end{array}$ & $\begin{array}{l}62 \\
25.5 \%\end{array}$ & $\begin{array}{l}21 \\
8.6 \%\end{array}$ & $\begin{array}{l}9 \\
3.7 \%\end{array}$ & 1.54 & 0.80 \\
\hline & \multicolumn{7}{|c|}{ Weighted Mean $=2.72$} \\
\hline
\end{tabular}


The finding above revealed that utilization of the Library was significant having scored a mean of 2.72. It therefore means that undergraduate students have the potentials to use their university libraries. However, seven of the 10 variables were significant while three were not. This implied that the library management needs to adopt strategies to encourage students to read library books, borrow them and use the e-resources provided in the library instead of depending on the lecture notes. At the Nnamdi Azikiwe University, Akwa, Anyaoku [26] obtained 84.8\% usage of their library by undergraduate students while Aladeniyi and Owokole [14] recorded high usage by majority of the undergraduate students in their university. Mwatela [27] found $77.55 \%$ of all levels of students visit the library with a purpose to use the services and resources.

Research Question 2: What is the joint contribution of academic discipline, level of study, gender and age on utilization of the library by undergraduates, University of Benin?

ANOVA result in Table 3 shows the joint contribution of the 4 independent variables (academic discipline, level of study, gender and age) to the prediction of the dependent variable i.e. utilization of the library. The result also shows a coefficient of multiple correlation $\left(\mathrm{R}=.270\right.$ and a multiple $\mathrm{R}^{2}$ of .073 . This means that $7.3 \%$ of the variance was accounted for by four predictor variables when taken together. The significance of the composite contribution was tested at $\alpha=0.05$. The result also shows that the analysis of variance for the regression yielded F-ratio of 4.672 (significant at 0.05 level). This implies that the joint contribution of the independent variables to the dependent variable was significant and that other variables not included in this model may have accounted for the remaining variance. Therefore, demographic characteristics (academic discipline, level of study, gender and age) of the students jointly influenced utilization of the library. Similar finding by Tolutope [19] revealed a joint effect of demographic variables on utilization of library software by undergraduates. Emiri [22] found that age, gender and level of study significantly influenced the use of OPAC. Stone and Collins [6] also found significant relationship between demographic variables and library usage in the UK.

Table-3: Summary of Regression analysis showing joint contribution of Faculty, Level of study, Gender and Age on Utilization of the library

\begin{tabular}{|l|l|l|l|l|l|l|}
\hline R & \multicolumn{2}{|l|}{ R Square } & Adjusted R Square & \multicolumn{2}{l|}{ Std. Error of the Estimate } \\
\hline .270 & .073 & .057 & 5.1537 \\
\hline \multicolumn{7}{|c|}{ A N O V A } \\
\hline Model & Sum of Squares & DF & Mean Square & F & Sig. & Remark \\
\hline Regression & 496.414 & 4 & 124.104 & 4.672 & .001 & Sig. \\
Residual & 6321.495 & 238 & 26.561 & & & \\
Total & 6817.909 & 242 & & & & \\
\hline
\end{tabular}

Research Question 3: What is the relative contribution of academic discipline, level of study, gender and age on utilization of the library by undergraduates, University of Benin?

To further confirm the influence of demographic characteristics of the students on utilization of the library, further analysis was performed on the data. Table 4 reveals the result of the relative contribution of the four independent variables to the dependent variable, expressed as beta weights, viz: academic discipline $(\beta=-.045, P>.05)$, level of study $(\beta=-.265, \mathrm{P}<.05)$, gender $(\beta=-.101, \mathrm{P}>.05)$ and age $(\beta=.022, \mathrm{P}>.05)$ respectively. Findings indicate that level of study was significant and independently and significantly predict utilization of the library while academic discipline, gender and age could not. It therefore means that level of study of the students should be taken into consideration when planning library use. Agboola and Bamigboye [24] revealed significant influence of level of study on library use in one of the three universities studied. In other studies, Ebijuwa and Mabawonku [25] found that age made relative significant contribution but gender and academic discipline did not. Oyedum [5] also found that course of study made significant relative contribution to the use of university libraries while Tolutope [19] revealed relative contribution of gender on utilization of library software.

Table-4: Summary of regression analysis showing the relative contribution of Faculty, Level of study, Gender and Age on Utilization of the library

\begin{tabular}{|l|l|l|l|l|l|}
\hline \multirow{2}{*}{ Model } & \multicolumn{2}{|c|}{ Unstandardized Coefficient } & Standardized Coefficient & t & Sig. \\
\cline { 2 - 5 } & B & Std. Error & Beta Contribution & & \\
\hline (Constant) & 31.615 & 1.664 & & 18.998 & .000 \\
Faculty & $-8.605 \mathrm{E}-02$ & .121 & -.045 & -.712 & .477 \\
Level of study & -1.009 & .244 & -.265 & -4.140 & .000 \\
Gender & -1.079 & .680 & -.101 & -1.586 & .114 \\
Age & .289 & .833 & .022 & .347 & .729 \\
\hline
\end{tabular}




\section{CONCLUSION AND RECOMMENDATIONS}

The relative influence of four demographic characteristics was investigated in this study. Based on the findings of this study, it can be concluded that demographic characteristics of undergraduate students influenced utilization of the library especially the relative influence of level of study. Efforts should be put in place by the managers of the library to sustain this result and improve on the level of utilization of the library. Undergraduate students at all levels should be encouraged to use the library.

\section{REFERENCES}

1. Quadri, G.O. (2013). Influence of demogr5aphic factors on use of online library resources by undergraduate students in two private university libraries. Library Philosophy and Practice (e-journal). 976. http://digitalcommons.unl.edu/libphilprac/976.

2. Usoro, I.P., Umoren, E., \& Akwang, N.A. (2018). Students' characteristics and information resources utilization in the University of Uyo library. International Journal of Information Science Studies, 4(3), 40-51.

3. Mahmood, K. (2013). Relationship of students' perceived information literacy skills with personal and academic variables. Libri, 63(3), 232-239.

4. Ebijuwa, A.S., \& Mabawonku, I. (2019). Demographic variables and academic discipline as determinants of undergraduates' use of electronic library resources in Federal universities in South-west, Nigeria. Library Philosophy and Practice (e-journal). 2164. http://digitalcommons.unl.edu/libphilprac/2164.

5. Oyedum, G.U. (2012). Relative effect of environmental factors, information literacy, course of study and resource availability to students' use of university libraries in Nigeria. Information Impact: Journal of Information and Knowledge Management, 3(1\&2), 1-19.

6. Stone, G., \& Collins, E. (2013). Library usage and demographic characteristics of undergraduate students in a UK university. Performance Measurement and Metrics, 14(1), 25-35.

7. Shane, N., Fransen, J.L., Peterson, K., \& Mastel, K. (2013). Analyzing demographics: assessing library use across the institution. Portal: Libraries and the Academy, 13(2), 131-145.

8. Lopatovska, I., \& Regalado, M. (2016). How students use their libraries: a case study of four academic libraries. College \& Undergraduate Libraries, 23(4), 381-399.

9. Thill, M., Rosenzweig, J.W., \& Wallis, L.C. (2016). The relationship between student demographics and students engagement with online library instruction modules. Evidence Based Library and Information Practice, 11(3), 4-15.

10. Jara, M., Clasing, P., Gonzalez, C., Montenegro, M. Kelly, N., Alaron, R., Sandoval, A., \& Saurina, E. (2017). Pattern of library use by undergraduate students in a Chilean university. Portal: Libraries and the Academy, 17(3), 595-615.

11. Gurika, R., \& Gurika, R. (2015). Use of library resources and services by Karanatak University Research Scholars: a case study. DESIDOC Journal of Library \& Information Technology, 35(5), 361-367.

12. Onovughe, B.C. \& Ogbah, E.L. (2013). Gender difference in the use of library among students of College of Education in Delta State. Information Technologist (The), 10(1), 165-172.

13. Momodu, O.M. (2014). Gender difference in library literacy among medical students in College of Medicine, Ambrose Alli University Ekpoma. International Journal of Basic, Applied and Innovative Research, 3(2), 60-64.

14. Aladeniyi, F.R., \& Owokole, T.S. (2018). Utilization of library information resources by undergraduate students of University of Medical Science Ondo, Ondo State, Nigeria. American International Journal of Contemporary Research, 8(4), 92-99.

15. Obasuyi, L., \& Idiodi, E.O. (2016). Influence of library value on library use: undergraduate students' perception study. International Journal of Library Science, 14(1), 56-67.

16. Nwezeh, C.M.T., \& Shabi, I.N. (2011). Students use of academic libraries in Nigeria: a case of Obafemi Awolowo University library, Ile-Ife. Library Philosophy and Practice 2011.

17. Oyeniyi, A.S. (2013). Gender differences in information retreieval skills and use of electronic resources among information professionals in South-western Nigeria. International Journal of Library and Information Science, 5(7), 208-215

18. Fumilayo, D.C. (2013). Gender difference in the use of academic resources: the case of FUTA library. International Journal of Library and Information Science, 5(8), 256-261.

19. Tolulope, A. (2017). Demographic variables as factors influencing accessibility and utilization of library software by undergraduates in two private universities in Nigeria. Journal of Education and e-Learning Research, 4(3), 92-99.

20. Ahmed, H.M. (2015). Gender difference in students' utilization of electronic information resoirces in Ramat library, university of Maiduguri, Nigeria. Information Impact: Journal of Information and Knowledge Management, 6(1), 61-71.

21. Bassi, M.D., \& Camble, E. (2011). Gender difference in use of electronic resources in University libraries of Adamawa State, Nigeria. Library Philosophy and Practice (e-journal). 549. http://digitalcommons.unl.edu/libphilprac/549. 
22. Emiri, O.T. (2015). Influence of demographic factors $\mathrm{N}$ use of Online Public Access Catalogue (OPAC) by undergraduates in selected university libraries in Southern Nigeria. International Journal of Scientific and Technological Research, 4(7), 164-169.

23. Uzuegbu, C.P., Chukwu, O.C., \& Ibegwam, A. (2012). Creating universal resource locator links on library computers desktop: a panacea for students' underutilization of subscribed electronic databases in academic institutions in Nigeria. Annals of Library and Information Studies, 59(2), 97-105.

24. Agboola, I.O., \& Bamigboye, O.B. (2011). Students' level of study and user of library resources in Nigerian universities: a comparative study. Library Philosophy and Practice (e-journal). 528. http://digitalcommons.unl.edu/libphilprac/528

25. Ebijuwa, A.S. (2018). Gender differentiation and perceived ease of usage of electronic resources by university students in selected private universities in Nigeria. SRELS: Journal of Information Management, 55(3), 117-127.

26. Anyaoku, E.N. (2015). Evaluating undergraduate students' awareness and use of medical library resources: a study of Nnamdi Azikiwe University, Nigeria. International Journal of Library Science, 4(3), 53-58.

27. Mwatela, W.M. (2013). Factors influencing utilization of library services and resources: the case of University of Nairobi Mombasa campus library. A research project submitted in partial fulfillment of the requirement for the award of a degree of Master of Arts in project planning and management of the University of Nairobi. http://handle.net/11295/63088. 